Old Dominion University

ODU Digital Commons

\title{
Teachers' Efforts to Support Undocumented Students Within Ambiguous Policy Contexts
}

\author{
Hillary Parkhouse \\ Virginia R. Massaro \\ Old Dominion University, vmassaro@odu.edu \\ Melissa J. Cuba \\ Carolyn N. Waters
}

Follow this and additional works at: https://digitalcommons.odu.edu/teachinglearning_fac_pubs

Part of the Bilingual, Multilingual, and Multicultural Education Commons, Educational Leadership Commons, Immigration Law Commons, and the Social and Philosophical Foundations of Education Commons

\section{Original Publication Citation}

Parkhouse, H., Massaro, V. R., Cuba, M. J., \& Waters, C. N. (2020). Teachers' efforts to support undocumented students within ambiguous policy contexts. Harvard Educational Review, 90(4), 525-549. https://doi.org/10.17763/1943-5045-90.4.525

This Article is brought to you for free and open access by the Teaching \& Learning at ODU Digital Commons. It has been accepted for inclusion in Teaching \& Learning Faculty Publications by an authorized administrator of ODU Digital Commons. For more information, please contact digitalcommons@odu.edu. 


\section{PRE-PRINT VERSION}

The following is the authors' final draft of a manuscript that was accepted for publication and, after editing and typesetting, was published as:

Teachers' Efforts to Support Undocumented Students Within Ambiguous Policy Contexts HILLARY PARKHOUSE, VIRGINIA R. MASSARO, MELISSA J. CUBA, AND CAROLYN N. WATERS

Harvard Educational Review, vol. 90:4 (Winter 2020) pp. 525-549.

https://doi.org/10.17763/1943-5045-90.4.525

Websites with the final published article (paywall):

HEPG website

https://www.hepg.org/her-home/issues/harvard-educational-review-volume-90,-issue-

4/herarticle/teachers\% $\% 2 \% 80 \% 99$-efforts-to-support-undocumented-students

HER electronic archive

https://meridian.allenpress.com/her/article/90/4/525/450390/Teachers-Efforts-to-Support-

Undocumented-Students

This copy is intended for non-commercial research and educational use, including for instruction at the author's institution and sharing with colleagues, as well as for archiving purposes. All other uses, such as reproduction and distribution, or selling or licensing copies, or posting to third party websites, are prohibited.

For further information, or for permission to reprint or to purchase copies of the final published version of the article, please contact Harvard Education Publishing Group (HEPG) at hepg@harvard.edu, or 617-495-3432.

The Harvard Educational Review (ISSN 0017-8055) is a scholarly journal of opinion and research in education. Its mission is to provide an interdisciplinary forum for discussion and debate about education's most vital issues. Since its founding in 1930, the Review has become a widely recognized journal in education, with circulation to policymakers, researchers, administrators, and teachers. The Review is published by Harvard Education Publishing Group.

Contact HEPG at:

8 Story Street, 1st Floor

Cambridge, MA 02138

$617-495-3432 \mathrm{ph}$

617-496-3584 fax

hepg@harvard.edu

http://www.harvardeducationalreview.org

Thank you. 


\title{
Agile Advocacy: \\ Teachers' Efforts to Support Undocumented Students Within Unclear Policy Contexts
}

\begin{abstract}
Although education scholars have recently focused greater attention on the experiences of undocumented youth in schools, few studies have examined educators' perceptions of their roles and responsibilities with regards to this population. Since the 1982 Supreme Court decision Plyler v. Doe guaranteed education to this group and barred schools from inquiring about immigration status, little additional policy has offered guidance on how schools can support this group while also refraining from identifying its members. Policies are particularly lacking in new destination areas where there are fewer resources and less infrastructure for new immigrant populations. As increasingly harsh immigration enforcement policies amplify fear and anxiety among families, educators and other service providers are more in need of support than perhaps ever before. Some teachers in new destination areas, however, have found ways to create safe and empowering spaces for undocumented students. We conducted a qualitative case study to explore how such educators understand their roles amidst both this policy void and a political climate in which immigration has become an especially contentious and divisive issue. We interviewed 18 teachers of immigrant students in one new destination area in Virginia, a state experiencing an increase in the undocumented population. We found that teachers took actions to enhance students' feelings of security and normalcy through curricular decisions, emotional support, and even the provision of basic needs. Teachers' actions, which were often spontaneous, adaptive, and resourceful, could be described as agile advocacy. These actions ranged from providing information to families to pushing for school and district policy changes. However, the teachers also encountered many barriers and few supports in these efforts. They felt largely alone
\end{abstract}


and frustrated by the incomprehensibility of the immigration system and the absence of buildingand district-level leadership in support of undocumented students.

Keywords: undocumented immigrants, educational policy, elementary secondary education, immigration, teacher role, case studies 


\section{Agile Advocacy: Teachers' Efforts to Support Undocumented Students Within Unclear Policy Contexts}

Given that approximately $7.3 \%$ of the K12 population are undocumented immigrants or children of undocumented immigrants (Passel \& Cohn, 2016), the research on how schools and educators respond to their unique needs is shockingly scant. The last decade has seen an increase in studies of the experiences of undocumented youth at school; however, most of these were in higher education settings (Gonzales, Heredia, \& Negrón-Gonzales, 2015). Of the few studies within K12 contexts, few have collected data on the experiences and perspectives of school personnel with regard to this population (Jefferies \& Dabach, 2014). As a result, we know little about the supports and barriers educators encounter in their efforts to meet the specific needs of undocumented students.

To understand their roles and responsibilities in working with undocumented children, educators have little policy to guide them. The question of whether this group is guaranteed a free K12 public education was not settled until 1982, with the Supreme Court decision of Plyler v. Doe (1982). That decision established that schools could not deny education to a child on account of their immigration status. Moreover, to prevent school actions from producing any sort of "chilling effect" (Plyler v. Doe, 1982) that might prevent families from enrolling their children, schools are not permitted to require social security numbers or proof of legal residency from families. Beyond these broad parameters, however, schools have little guidance on how to ensure they provide a safe and inclusive learning atmosphere for these children while remaining within the bounds of the law. Ultimately personnel typically resort to a “don't ask, don't tell” policy which hampers their ability to provide the supports students need (Jefferies \& Dabach, 2014; Mangual Figueroa, 2011). Furthermore, the rise in xenophobic rhetoric and anti- 
immigration policies since the presidential campaign and election of Donald Trump have intensified fear and uncertainty among the undocumented population, children included. Educators have even less guidance on how to care for these youth while recognizing the realities they face during this era of heightened immigration uncertainty and xenophobia.

At the same time, some recent literature has illuminated the ways in which teachers can provide safe and welcoming environments for undocumented students (Dabach, Fones, Merchant, \& Adekile, 2018). The present study seeks to further the knowledge base regarding educators who wish to support and advocate for undocumented students by exploring three questions:

1. How do these teachers perceive their roles and responsibilities as they relate to undocumented immigrant students?

2. How do they fulfill these responsibilities and perform these roles?

3. What supports and barriers have they encountered in attempting to fulfill these perceived responsibilities?

We chose Virginia as the location for this case study due to the fact that it has a rapidly growing new immigrant population and lacks the experience and infrastructure that traditional gateway states such as California, Texas, and New York have (Rong, Dávila, \& Hilburn, 2011). As a result, states like Virginia have fewer established policies related to integrating newer immigrant families into communities and schools. We recruited teachers working in one metropolitan region considered a new Latino destination, meaning the Latino population growth exceeded 235\% between 1980 and 2000 (Suro \& Singer, 2002). Such areas appear to have fewer local policies such as school board regulations to guide educators, leaving them particularly uncertain about what they are and are not allowed to do to support their undocumented students. 
Given that over half of the nation's 100 largest metropolitan areas are considered new Latino destinations (Suro \& Singer, 2002), we believe this is an important context to study. Educators in many of these metropolitan areas may be experiencing similar unclear policy contexts as did the teachers in this study.

We begin the paper with a description of the context of unauthorized migration to the United States and Virginia and policies relevant to educators, followed by a review of the literature on undocumented youth in schools and educators' perspectives on their work with this population. Next, we describe our research methods for this qualitative case study. The findings section is subdivided into three subsections which correspond to the three research questions. Finally, we discuss how these findings build on prior literature and implications for policy and practice.

\section{Background}

Undocumented Immigrants in the United States and Virginia

For much of United States history, legal migration was not strongly enforced, leading to millions of undocumented immigrants residing in the country by the 1980s. President Reagan provided amnesty and legal status to those migrants through the 1986 Immigration Reform and Control Act. Since then, anti-amnesty positions have grown alongside a criminalization of unauthorized migration. The government's response to the September 11 attacks exacerbated this trend through the creation of U.S. Immigration and Customs Enforcement (ICE) with its broad powers of deportation (Jefferies, 2014a; Jefferies \& Dabach, 2014; Migration Policy Institute [MPI], 2013).

The last three decades have also seen a proliferation of messages about undocumented migrants stealing jobs, draining American resources without paying taxes, and committing 
crimes. In reality, undocumented immigrants commit fewer crimes than legal residents, and they do pay income taxes and contribute to social security although they are ineligible to receive social security and most other government benefits (Castro-Salazar \& Bagley, 2010; Cisneros \& Lopez, 2016). These are just a few examples of the widespread misconceptions fueled by inflammatory nativist rhetoric. These fallacies, in turn, contribute to support for inhumane policies and practices such as separating children, including infants, from their parents - a policy initiated under the Trump administration in an attempt to deter migration (Francis, Wachendorfer, \& Wilson, 2018).

Despite growing immigration enforcement over the past few decades, migration from the Northern Triangle (El Salvador, Honduras, and Guatemala) remains high and includes many unaccompanied minors and children arriving in family groups (Cohn, Passel, \& GonzalezBarrera, 2017; U.S. Customs and Border Protection, 2019). Migration from this area has been particularly high to Virginia, which now ranks ninth overall in the country for its population of undocumented immigrants (MPI, 2014). Although exact numbers of undocumented immigrants are unavailable for the particular school districts relevant to this study, we did obtain Virginia Department of Education enrollment data showing that the English Learner population doubled or tripled in each of these districts, and the ESOL teachers reported the majority of new English Learners were indeed undocumented and often unaccompanied minors.

\section{Policy Contexts}

The two school districts in which all but one of our participating teachers taught had no school board policies, resolutions, or statements of any kind related to serving undocumented students that we were able to locate. This is in contrast to another school district in the state, with a longer history of large-scale immigration, which issued statements of inclusivity following the 
November 2016 election and published the statements in four languages on its website. That district also has a permanent page on its website entitled "Immigration Supports" that reassures families that the district does not solicit or release any immigration-related information, that ICE issued a 2011 memo stating it would not conduct activity in sensitive locations such as schools (although it remains legal for them to do so), and that if ICE were to question a student, the school district would notify parents so they can attend if possible and, if not, an administrator would attend. The webpage also has hyperlinks to many resources for immigrant families. One high school in that same district has a webpage that lists resources specific to DACA (Deferred Action for Childhood Arrivals) and college information for undocumented students. The existence of these resources in one school district in the state demonstrates that it would be possible for the districts in our case study to do the same. However, as will be described in the findings, teachers' efforts to get their districts to make such resources available were unfruitful.

In terms of state policy, teachers could look to a memo issued by the State Superintendent of Public Instruction on March 1, 2017; however only one of our participants expressed awareness of this memo. The memo stated, "Local school divisions have a constitutional and statutory obligation to provide education to K-12 students regardless of their immigration status, and to take active steps to guard the public education rights of students" (Staples, 2017, p. 1). The memo also stated that it is not a violation of immigration law or executive actions to provide "general information to families about their legal rights, and referrals to seek legal assistance if they need it" (Staples, 2017, p. 1). The memo goes on to state that ICE officials must present a warrant before entering school grounds and recommends that school officials work with an immigration advisor to review any subpoenas before releasing student records and to develop a plan to respond to requests by immigration officials. These guidelines provided some degree of 
information for teachers regarding their rights to support students; however, the memo was addressed to district superintendents and did not appear to be disseminated to educators or immigrant families.

\section{Undocumented Youth and Schools}

Despite the intent of Plyler to prevent undocumented children from facing "a lifetime of hardship" (paragraph b), those who graduate from high school are nevertheless limited to predominantly low-wage jobs as a result of work eligibility requirements, disqualification from federal financial aid, and ineligibility for in-state college tuition rates in most states including Virginia $^{1}$ (Gonzales et al., 2015; Jefferies, 2014b; National Academy of Sciences, Engineering, \& Math [NASEM], 2017). Their status also prevents them from obtaining a driver's license in many states, including Virginia (NASEM, 2017). Therefore, many undocumented students, after becoming aware of the limited value a high school diploma holds for them, elect to leave school early (Lopez, 2010). They often experience liminal citizenship where they do not feel they fully belong in their home country or in the United States (Torres \& Wicks-Asbun, 2014).

A large proportion of undocumented immigrant students have experienced trauma and psychological stress associated with migration experiences, family separation or threat of separation, and/or family reunification (Gaytan, Carhill, \& Suarez-Orozco, 2007; NASEM, 2017; Rong, Dávila, \& Hilburn, 2011). Although ICE issued a memorandum in October 2011 stating that schools are sensitive locations where arrests and interviews are prohibited, it also added that there can be exceptions to this rule "when there is an immediate need for enforcement action" (Morton, 2011, p. 2). The fear resulting from this threat can prevent parents from advocating for

\footnotetext{
${ }^{1}$ In 2014, Virginia's attorney general granted in-state tuition to DACA recipients (National Conference of State Legislatures, 2019); however, many students of the teachers in our study arrived too recently to be eligible for DACA.
} 
better schooling conditions or for resources their children might need such as special education services (NASEM, 2017). Teachers are also hampered by the fear of exposing a child's status, resulting in a circle of silence that promulgates existing misconceptions about undocumented youth (Jefferies, 2014a, p. 192). As a result of these factors and the fact that undocumented students disproportionately attend lower-resourced and lower-performing schools, "just 54 percent of undocumented youth have at least a high school diploma, compared to 82 percent of their U.S.-born peers" (USDOE, 2015, p. 3), and the college matriculation rate for undocumented student graduates is only 5 to 10 percent (USDOE, 2015).

These realities may paint a picture of undocumented youth as victims, so we also want to highlight the many examples of activism and resilience among this population. Several studies have highlighted examples of undocumented youth organizing to fight for immigrant rights, the DREAM Act, and in-state tuition legislation (Gonzales, 2008; Negron-Gonzales, 2014; Parkhouse, 2017). Lopez (2010) proposed the concept of transnational resilient resistance to address how undocumented students have demonstrated resilience in their educational trajectories by finding alternative opportunities after high school beyond traditional higher education.

\section{School Professionals' Perspectives on Teaching Undocumented Students}

A growing body of research has illuminated undocumented students' experiences in schools including their navigations of citizenship education and decisions about whether, to whom, and how to disclose their status (Dabach et al., 2018; Gonzales et al., 2015; Mangual Figueroa, 2017; Negrón-Gonzales, 2014). However, few researchers have attempted to understand school conditions for these youth from the perspectives of the educators attempting (or not attempting) to serve them. 
Schools are positioned to integrate undocumented students into the community and provide "spaces of belonging that supersede legal citizenship" (Gonzales et al., 2015, p. 329). Teachers, counselors, and other school professionals can aide undocumented students with educational materials, emotional support, social networks, humanizing language, and a space to consider the implications of revealing their legal citizenship status and its relation to broader historical and political contexts (Castro-Salazar \& Bagley, 2010; Mangual Figueroa, 2017; Núñez \& Holthaus, 2017). Gonzales, Suárez-Orozco, and Dedios-Sanguineti (2013) found that undocumented students who "were able to maintain strong friendships or had caring adults (teachers, counselors, or other adult mentors) with whom they could talk openly about their struggles described less emotional distress and were much more likely to remain at school" (p. 1188).

However, schools do not often live up to their potential to moderate the stress arising from traumatic migration experiences, family separation, and anxiety about anti-immigrant policies and attitudes (Gallo \& Link, 2016; Gonzales et al., 2015; Jefferies, 2014a, 2014b). Some school staff are unaware or unconvinced of their obligation to provide a safe and welcoming education for these youth (Lopez, 2010). Some even believe they are mandated to report students' disclosures about being undocumented (Gallo \& Link, 2016). After finding this to be the case in the school Gallo and Link (2016) studied, the authors offered the following explanation:

Even though almost half of [the school's] students were from immigrant families, no professional development had been offered to support teachers in how to navigate 
immigration status and schooling, Plyler and its implications for talking about undocumented status were not discussed, and teachers were left to their own devices. (p. 189)

Even among caring staff there is often still a "circle of silence" resulting from a fear that any discussion of status may put students at risk (Jefferies, 2014a). Moreover, teachers need training on how to ensure their instruction does not inadvertently marginalize or silence these youth. Even assignments designed to promote inclusivity, for instance through having students describe their various family histories, may have the reverse effect if students are fearful of sharing aspects of their identity such as their country of birth (Mangual Figueroa, 2017).

Some teachers have learned, often on their own, ways to support and advocate for these students. Jefferies and Dabach (2015) studied teachers who worked to normalize undocumented status by teaching appropriate terminology and discussing scholarship opportunities available to undocumented youth broadly to the class without calling anyone out. In another study, civics teachers used various strategies to promote safety and inclusivity in conversations about citizenship when citizenship status cannot be assumed (Dabach, Fones, Merchant, \& Adekile, 2018). Some organizations are beginning to provide professional development for postsecondary educators through specifically designed trainings like DREAMzone, UndocuAlly, and UndocuPeers (Cisneros \& Lopez, 2016). Although we did not encounter examples in the literature of such trainings at the K12 level, three of the four authors of this paper were involved in adapting a higher education-based UndocuAlly training for K12 personnel (described below).

\section{Method}

Site and Study Design 
This study employed a qualitative case study design (Merriam, 1998), described as the "examination of a specific phenomenon in a bounded system" (p. 9). This design was chosen because we sought to understand how teachers of immigrant students in one metropolitan region experiencing high undocumented immigration perceive and fulfill their roles and responsibilities as they relate to undocumented students. The site was a new Latino destination metropolitan region (Suro \& Singer, 2002) in Virginia, a state experiencing rapid growth in the immigrant population over the prior decade. We selected this site because our work with teachers in the region had revealed to us that many local educators were frustrated by the lack of guidance and support available to help them serve undocumented students. Our data consists of 18 in-depth interviews, all of which were conducted between July 2017 and March 2018. We selected interviews as the primary data source due to our interest in educators' perspectives, as opposed to their teaching practices or other phenomena that might be captured through observation or other data collection methods.

\section{Participants}

We used purposeful and snowball sampling (Merriam \& Tisdell, 2016) to recruit school professionals interested in sharing their perspectives on working with undocumented students. The UndocuAlly training mentioned above provided us with an initial list of potential participants. The training was co-sponsored by a local teacher advocacy group and a university group of Latinx students and allies who had already developed an UndocuAlly training for faculty and staff at their university. Two trainings were held, each consisting of a one-day workshop held on a Saturday in the spring of 2017. From the pool of attendees, we recruited via email and later sought additional participants through snowball sampling (Merriam \& Tisdell, 2016). Although we had hoped to include educators of a variety of content areas and grade 
levels, all but two of those who responded to our call were teachers of English to Speakers of Other Languages (ESOL). The remaining two were a Spanish teacher and a special education teacher. The participants were from a variety of grade levels, however, as well as schools. Table 1 provides additional details about the participants.

\section{[INSERT TABLE 1 ABOUT HERE]}

The first two authors conducted all 18 interviews, which were semi-structured and lasted between 30 and 90 minutes. All interviews were conducted in person. We asked questions such as, "Describe a few experiences you have had that made you more aware of the unique situations of undocumented students" and, "What do you perceive to be some areas in which your school could improve in supporting undocumented students?" The first interview was conducted with both the first and second authors present, in order to refine the interview protocol and ensure relative consistency across interviews. The first or second author separately conducted all remaining interviews. We concluded recruiting participants once saturation occurred in the data collection and we began to notice themes repeating (Merriam \& Tisdell, 2016). The second author transcribed all interviews.

\section{Data Analysis}

The authors collaborated in four phases of thematic analysis of the interview data (Braun \& Clarke, 2012). During the first phase, all four authors met to simultaneously open-code two dissimilar transcripts line-by-line to develop an initial codebook. We collaboratively developed descriptions of each code to ensure all researchers shared a common understanding of the codes. During phase two, each author coded half of the remaining data, so that each transcript was ultimately coded by at least two researchers. In phase three, the whole research team met to discuss hard-to-code quotations, revisions that we needed to make to the codebook, and initial 
ideas for conceptual themes and categories. During the fourth and final phase, the research team finalized themes, discussed counter-examples, and sought to confirm, complicate, or challenge the existing literature. This collaborative analysis process, which has been referred to as "the interpretive zone" (Wasser \& Bresler, 1996), placed our sometimes-divergent interpretations in conversation with each other to ultimately lead to deeper understanding. To further enhance the trustworthiness of the findings, we used member checking and incorporated participants' feedback into the final report (Merriam \& Tisdell, 2016).

\section{Limitations}

Our method of purposeful and snowball sampling intentionally elicited perspectives from teachers sympathetic to undocumented students. Thus these findings are not intended to generalize to the population of teachers, many of whom may be ambivalent or even opposed to educating undocumented students. Moreover, about half of the participants had attended the UndocuAlly training and all self-selected to participate; therefore these teachers have demonstrated that they are particularly interested in learning how to support and advocate for undocumented students. In this way they are not representative of all teachers; however, they do serve as a critical case (Flyvberg, 2001) in that whatever supports and barriers these teachers identify are likely to hold true for teachers who may not be as actively thinking about supports and barriers.

Our findings are also not necessarily generalizable to K12 public school teachers in other geographic locations, which may have different policies or practices. Although we interviewed teachers until the point of data saturation, it is possible that including more participants could have surfaced other findings. Future researchers should seek perspectives of teachers of other 
disciplines such as math, science, and social studies to investigate how perceived responsibilities and supports may differ by content area.

The interviewers were both White, native English-speaking females born in the United States and working at a university, so their privileged social positions may have affected participants' responses in some cases. We attempted to build trust and rapport through sharing our prior experiences as K12 educators of immigrant students. The interviewers did not know most of the teachers prior to conducting the interviews, however, so teachers may have felt less comfortable than they would have otherwise. However, the lack of relationship may also have helped respondents feel more anonymous and thus secure in disclosing sensitive information.

\section{Results and Interpretation}

\section{Perceived Roles and Responsibilities}

The following two quotes illuminate how the teachers perceived their roles as extending beyond that of the teacher and into that of the social worker and guidance counselor: "We're so much more than teachers. I mean we're social workers; we're mediators" (Brin); "My role that I've taken on is that kind of social worker, guidance counselor, you know, I speak Spanish. I call parents" (Molly). Thus teachers faced a paradox in that, although they had an ethical obligation to support students' specific needs, they could not inquire about those needs if they pertained to immigration status. Whereas Plyler established a system in which status is withheld from schools, the reality these teachers faced was that the immigration and educational systems are far more entangled than policymakers may like to believe.

\section{Regarding Status Disclosure and Involvement}

All teachers conveyed their awareness that schools are prohibited from asking families about immigration status. However, Rachel felt that, as a high school teacher attempting to help 
students navigate college decisions, she could only fulfill this role if she knew their status because this impacts which funding sources are open to them and their eligibility for in-state tuition. She also recounted instances in which she inferred students' status, even while they did not know it themselves, through noticing missing social security numbers on forms. Another teacher, Stacy, reported that attorneys had contacted her to confirm that their clients' children were attending school and to inquire about their grades, as part of guardianship cases necessary before moving forward with immigration proceedings. Thus the question of whether or how teachers discovered students' immigration status was more complicated than whether or not students chose to disclose it.

Another complicated question for teachers was how involved to be in families' attempts to secure authorized status. Most teachers seemed to feel similarly to Olivia when she said, "you can't do something about whether they're deported or not necessarily.” However, one teacher, Brin, felt compelled to try to understand the system so that she could help families obtain authorization. Brin was frustrated by what appeared to be a nonsensical system in which students had to miss school for court dates and then some students were able to obtain green cards while others were not. As a result of this frustration, Brin and her colleagues researched the immigration legal services the families were using and tried to learn more about how families could attain legal status. However, they were unable to obtain much clarity due to the fact that "it's all so case-by-case specific" (Brin). Several other teachers expressed that they also were pursuing more knowledge of immigration law but agreed that the complexities of the system hindered meaningful understanding.

\section{Providing Safe, Supportive Spaces}


All teachers reflected a desire to provide a safe, reassuring, and inclusive place for students who had experienced trauma both before and while migrating, and who continued to live in a state of fear. Prudence described a day when she announced it was time to go to lunch and a typically mild-mannered child "went into hysterics." Prudence discovered that the girl's father had been deported the week prior and that her mother had told her she would pick her up before lunch today. When her mother failed to arrive on time, the child assumed she had also been deported and cried, "Who am I going to go home to? They got my mommy. My daddy is gone. I have nowhere to go.”

Each teacher reported stories that students and families shared regarding the violence they had witnessed or experienced in their home countries, their journey into the United States, and their loss of loved ones to deportation. Below are just a few more of the many examples:

A father of a first grader came rushing into the office and I was called up to talk to him. He was agitated and he said that ICE had come to his door before light. He answered the door and they rushed past him, took his wife out of bed and immediately deported her to El Salvador. He, as a dishwasher who had to go to work at 12:00, was concerned that he had no place for his child to go after getting off the bus. (Olivia)

[One student who'd been having panic attacks] and her brother were coming from Guatemala, and. . they get on a boat and they come into Mexico. And, they were walking on some gangplank and there was another woman holding her baby. The baby fell in the water ... right in front of [the student]. The baby was gone. (Brin) 
Hearing the specific traumas their students had survived took a toll on the teachers. Nicole described the work as "emotional labor," and Prudence lamented, "I am not emotionally strong enough to deal with the problems these kids have." Nevertheless, the teachers felt they needed to know this background information about their students so that they could make more informed interpretations of their behaviors and decisions about the best means of supporting their education and wellbeing.

\section{Fulfilling Perceived Responsibilities}

Based on their self-defined roles with regard to undocumented students, the teachers took a variety of actions to fulfill the responsibilities of supporting families within and outside of school. Teachers sometimes provided basic needs and often designed units and lessons that their students could relate to and that would allow them to process some of the traumas they had experienced. Teachers also took actions to advocate for their students, often independent of the school administrators who were typically less vocal due to concerns over political conflict.

\section{Provision of Basic Needs}

Teachers took actions to ensure students had basic needs such as food, books, eyeglasses, transportation to and from school, school supplies, and even just a safe space within the school. Prudence recounted an instance when a mother was afraid to sign the forms necessary for receiving free eyeglasses for her son:

My very first year teaching I had a student who needed glasses. This kid got here all the way on a bike from Honduras with him and his mom. Broke his glasses on the way here. . . His mother would have to come in and sign forms for him to receive free glasses. She was too afraid. . . She would say, in Spanish, "I cannot come. I will be taken away." I offered to come to her house. She goes, "That's not where we really live. You cannot 
come to my house." Finally, I was able to convince her [to] trust me enough [to] come here and fill this out.

Donna recalled how one parent kept her child home from school for two weeks because ICE had conducted a raid at a bus stop and thereafter the mother was afraid to walk her child there. Donna drove the child to school until the mother resumed bringing her to the bus stop. Brin allowed students to color in her room during her planning periods just so that they could "feel like they're doing something and that they are getting used to [the new school] system.” After Trump's inauguration Stacy's students were "feeling vulnerable" particularly because their classroom was in a trailer with one small window in the door. To help her students feel more secure she assigned one tall $7^{\text {th }}$ grade student to be "the door woman, and she would look out the window before she opened the door," only opening it if they recognized the visitor. She added, "Well, that's a lot of responsibility for this twelve-year-old girl, but she did it and she seemed okay with that. She's tall. She's good at it. But how can we [as adults] do that for kids, right?"

\section{Status-Responsive Curriculum}

Many of these teachers' curricular decisions were driven by a desire to emotionally support undocumented students and to help them feel more connected to one another and to the school. For instance, Molly bought copies of the novel La Linea by Ann Jaramillo (2006) for her $8^{\text {th }}$ graders. While reading about 15 -year-old Miguel and his perilous journey from Mexico to California to reunite with his parents, several of Molly's students told her, "Oh yeah I did that" or "Oh, my uncle did that." She said they looked forward to reading the book, adding "they have very few opportunities in school to read about anything that makes sense to them." Prudence helped students draw connections between their journeys to the United States and those of other groups of migrants throughout history. When we asked if the youth showed signs that reliving 
these experiences was painful for them, teachers replied similarly to Stacy when she said, "I think it might have been a relief perhaps to talk about it."

Occasionally world events would call for teachers to pause their planned curriculum to address students' anxieties and fears. One event many teachers mentioned was the election of Donald Trump. Stacy's class had been engaging in weekly restorative circles led by a school counselor in which one question posed to the group was, "What color is your mood?" Stacy said, "After the election, the color changed. There were no more pinks and purples. It was grays and blacks." Victoria designed a language lesson that served the dual purposes of allowing students to share their feelings about the election while also expanding their vocabulary. She explained, "I didn't talk, because we were forbidden to talk about the election essentially." Instead she led an activity she called "Words that Help:"

They had a whole vocabulary list and then they had to, on a sticky note, write a word you like when you feel nervous or unsure. And then write it in English and Spanish. ... I gave them construction paper and they made little charts and I said, "You can write anything." And one boy—and I still have it—he wrote this big paper that said, "Love people regardless."

These examples demonstrate how teachers attempted to weave into their curriculum opportunities for students to forge connections, normalize the migration experience, and lighten the burden of guarding a secret.

\section{Agile Advocacy}

Beyond interactions with students, teachers advocated on their behalf in a variety of ways, including providing contact information for legal and other forms of assistance as well as pushing administration to create more inclusive school climates or colleagues to be more 
sensitive. Although this advocacy was all part of a sustained movement toward greater inclusivity and support, individual actions were often spontaneous and agile responses to particular incidents. For example, Nicole recounted receiving an email from administration to remind parents they need to show identification in order to visit the school. Nicole wrote back, "While safety is my top concern as well, what about parents of students who don't have that? What are we going to do?" (She had not received a response at the time of our interview several months after the exchange).

Agile advocacy often arose in individual interactions with colleagues. Although all teachers said many of their colleagues showed empathy to undocumented families, most had also witnessed colleagues expressing anti-immigrant attitudes. Deborah said the staff at her school all used the term "illegal", adding, "nobody uses the word 'undocumented.' That's too favorable." In many cases, these teachers felt part of their responsibility was to address insensitive comments and uncaring attitudes among their peers. Rachel encountered a counselor who said, "Well, I don't think they should be here" to which she responded, "Well, they're here and we're in school and they're children.” Donna tried to explain to unsympathetic colleagues that undocumented or mixed-status families were

escaping from a life where they either were being persecuted or didn't have jobs or food or wanted to make a better life for their family. Wouldn't you do the same? That's usually what I'd say, you know, "You would do it too for your family."

Another element of teachers' advocacy consisted of requests to building-level and sometimes district-level administrators. These had not resulted in much success, however. Prudence expressed that the only way she had gotten administrators' attention was to raise the 
possibility of lawsuits given schools have a legal obligation to ensure their students feel safe and protected. Even then, however, no change resulted from the conversation:

The point that I've started bringing up to people that I've spoken to who are in positions of authority has been, "How far do we go until it's a legal repercussion?" And that's the only way I've been able to get anyone to respond. This is a pending legal suit. What can we do? And still [they say], "Oh, I don't know, what do you suggest?" [I reply,] "I'm not in charge here. Help me." So, they're not ready. (Prudence)

Molly had gone all the way up to the district superintendent in an attempt to get information on the district's website to support undocumented families as they sought resources following Trump's election and promises of mass deportations. Molly had noticed Denver Public Schools (2016) published a page on their website that included Immigration Rights FAQs in ten different languages and the following statement from its "Safe and Welcoming School District" Board Resolution in large font: "the district shall do everything in its lawful power to protect our students' confidential information and ensure that our students' learning environments are not disrupted by immigration enforcement actions." Molly wrote her district ESOL specialist, and later wrote her superintendent, to ask if their district could publish a similar page, but the response from both offices was that families know they can go to principals with these types of questions. Molly replied: "I don't agree with you, because not all principals believe the same thing. Not all families are comfortable speaking with principals, but if it was on the site their kids could see it. They could explain it to them." She went on to add, "The [district community relations] person said they would start a file. So, I started sending Teaching Tolerance [resources], and anything that I came across, [writing] 'Note for your file, for your file, for your 
file.' So, I'm that little jabber." Donna had requested similar action from her school board, but to no avail. These teachers nevertheless described ways in which they continually adapted their forms of advocacy to keep pace with ever-changing political circumstances. In this way, advocacy for undocumented students had to be agile in terms of both being adaptable to change as well as resourceful in the face of little or no guidance from school leadership. Teachers wishing to support immigrant students are left to improvise and rely on their instincts regarding the best actions to take. The following section describes the limited supports and substantial barriers teachers faced as they attempted to enact agile advocacy.

\section{Barriers and Supports}

The interviews revealed an overwhelming number of barriers to fulfilling the obligations these teachers felt they had to their students. One major challenge was that teachers felt "isolated and alone" (Victoria) in this work. Many additional barriers related to the students' English learner status and the inequities in education for students receiving ESOL services. However, for purposes of this article, we focus only on those barriers pertaining specifically to undocumented status. The teachers could not identify many supports, but we share the few examples they did mention at the end of this section.

\section{Chilling School Climates}

Teachers described a lack of support for undocumented youth at the school and district level, which in effect violates the provision of Plyler that prohibits schools from creating a chilling effect that might deter undocumented families from sending their children to school. For starters, no professional development or other interventions were provided to ensure all school personnel knew their legal obligation to provide safe and supportive environments for undocumented students, including the fact that they only have to cooperate with ICE under 
certain conditions. The State Superintendent's memo sent to all school districts (described in the background section) explicitly laid out this information; however, almost all teachers we interviewed said they were unaware of this memo or the policies it explained. One teacher had the misconception that essentially "the gist of [the policy outlined in the memo] is cooperate [with ICE].” Without a school-wide shared understanding of the obligation to reduce chilling effects, individuals within the school often took actions that undermined this requirement. To name just a few examples, teachers made insensitive or xenophobic comments like the examples mentioned above, and front desk staff sometimes mistakenly told families they needed a social security number in order to enroll their children. Catherine recounted a front desk staff person being unwilling to register a family who left their email address field blank, explaining "I don't want to be wrapped up with anything like that!" Implied in this statement was a fear of serving as an accomplice to a crime merely by registering a family. Olivia shared that her principal allowed a neighborhood group to put out a sign welcoming visitors in Spanish and Arabic but the principal was later told by the district to remove it for political reasons.

Some of the teachers thought their principals did not view the issue as a priority (Victoria) and others were unsure where their administrators stood, perhaps because in their attempts to be apolitical, they often avoided the topic. Deborah said, "I can't really get a sense of how our principal feels about it. She's, you know, she's wise enough to not say anything." Caroline said she would not share the status of her students with any administrators, regardless of their apparent support, because "we don't know who we can trust at the end of the day." Olivia described herself as "going undercover" in order to fulfill her responsibilities to students while also protecting her job. This uncertainty about the trustworthiness of building leaders may have been fueled by school structures that disserved immigrant and emergent bilingual students. 
Important intercom announcements regarding safety would be made only in English in schools with hundreds of Spanish speakers, leaving some students panicked about what information they missed (Kelly). Other teachers had to wander the halls with their ESOL classes in order to find a space to work, leaving English learners feeling spatially and socially marginalized. Victoria explained, "I have to go to four different rooms on four different hallways through the hallways in a school that has 1800 kids. . . so, there really isn't time to have personal conversation with the kids."

\section{Conflicting Expectations: Support Without Politics}

Another barrier for these teachers was the conflicting expectations that they should support students emotionally and socially while also not taking any political positions. Several teachers said that their administrators had mandated that they "stay neutral" (Rachel) and had "forbidden [teachers] to talk about the [presidential] election essentially" (Victoria). As a result, they felt they were supposed to suppress their agreement with students' critiques of Trump's policies and rhetoric as xenophobic. Some teachers, like Donna, decided that caring for her students compelled her to join in students' denunciations of Trump's fear-mongering and xenophobic rhetoric. She stated,

All they know of Trump is he wants to ship them to a country they've never been to. Or ship their families who are undocumented, because a lot of my students were born here . . . One was crying. . I would let them talk. I probably wasn't allowed to in the eyes of my administration, but I would let them talk. I didn't want them to feel like they didn't have someone besides their family who felt the same way... I guess I'm not the kind of person that can just say, "Go ahead and tell me how you feel," and if Trump comes up, for me 
not to say something like, “I'm with you there." You know? It's just, I did want to hear their feelings, but I also wanted to let them know that I agreed with them.

Other teachers, particularly those newer to the profession, were more cautious. When we asked Nicole, who had been full-time teaching for less than a year, about barriers to her ability to support undocumented youth, the only barrier she identified was her fear of being perceived as "proselytizing" or engaging in political indoctrination. She showed one student the American Civil Liberties Union (ACLU) page with resources for undocumented immigrants in multiple languages, but did not print the page because "it is definitely a political organization. ... [and] I think that that could be viewed as proselytizing." Thus some teachers limited their supportive acts to those they could be sure would not risk breaching the district's limits on political speech ${ }^{2}$. Several participants also believed that part of the reason more of their colleagues were not allies to undocumented students was a fear of being viewed as political.

Some teachers, however, decided to risk disciplinary action or, worse, job loss, in order to explicitly condemn xenophobic political rhetoric. Olivia gave families the phone number for the Legal Aid Justice Center, explaining,

I don't see that as a political thing, I see that as the same as when the counselor says, "You've got this issue. Here's the number to social services or here's the number to a counselor" ... I just see it as one of many services that the community provides that

\footnotetext{
${ }^{2}$ The districts' policies on political activity essentially stated that employees could not use school time or property for partisan political purposes. Our participants displayed a range of interpretations of what precise actions this prohibited, particularly with regard to supporting undocumented students which they worried could be perceived as a partisan political issue.
} 
should be brought up and I'm just very disappointed that I've had to go undercover to do things.

Olivia also left ACLU pamphlets with a parent who owns a tienda, asking him to leave them out for people to take. She then co-hosted an information session for parents with the Legal Aid Justice Center at another ESOL teacher's house, without the knowledge of her administrator.

\section{Supports}

We asked participants to name any supports they have had in their work with undocumented students, but most could name one or two at most. The majority of teachers indicated they received little to no professional development on the subject beyond the independent UndocuAlly training (for those participants who had attended that training). No similar trainings had been sponsored by the school districts, further bolstering the teachers' claim that administrators failed to provide the information they needed. In terms of finding other resources to support families, participants largely echoed the following statement from Catherine: "There's some information that I can get from the family liaison for [my school district], but she's one person for all these families. So, honestly, I don't really know much about what's available around here." A few mentioned online resources they found like a list of scholarships that undocumented students are eligible for. One happened to be engaged to an immigration attorney, who was able to answer a few of her questions. Otherwise, teachers were largely educating themselves using whatever resources they could find and then developing their own strategies accordingly. This is another way in which they demonstrated agile advocacy. Nevertheless, all participants, including those who knew a great deal about the immigration system and this population of students, strongly expressed a desire for more leadership and professional development on this issue. 


\section{Discussion and Implications for Practice and Policy}

This study contributes to the small but growing body of literature on the ways in which the education guarantee of Plyler v. Doe "comes at the price of invisibility" (Mangual Figueroa, 2011, p. 263). Adding to this research base, these interviews highlighted ways in which teachers' efforts to increase students' visibility are often ignored. For instance, when one teacher urged the school district to post information for undocumented families on their district website, her efforts were repeatedly dodged. Other teachers provided resources to families without informing their administrators, using a logic of "it's better to ask forgiveness than permission" when they could not be sure if their actions would be permitted.

This study echoes earlier research calling for teachers to explicitly acknowledge the possibility that some of their students may have undocumented status (Jefferies \& Dabach, 2014) and adds examples of ways in which status consciousness can help teachers better serve their students. First, status consciousness allowed educators to better understand students' material and emotional needs, and also to meet them (e.g., through providing safe spaces and even basic needs such as transportation to school). It also increased the likelihood of families receiving information about community resources such as legal aid. Finally, and perhaps most importantly, the findings showed how 'teachers' acknowledgement and normalization of undocumented migration can potentially partially combat aspects of 'illegality' that render youth as less than human and less than equal members of society" (Jefferies \& Dabach, 2014, p. 85).

The problem — as revealed through this study — is that teachers are often largely alone in their agile advocacy, and they face many obstacles including lack of administrative support, prejudices of colleagues, and an inability to achieve sufficient understanding of their students' situations given the incomprehensibility of immigration proceedings. Whereas earlier studies 
showed how lack of status-consciousness could hamper teachers' abilities to support students (Gallo \& Link, 2016), this study shows how even status-conscious teachers actively seeking information often struggle to find clarity on policies related to both immigration and its relationship to education. For instance, teachers in this study were not sure how much they could disclose their own political leanings in order to express empathy for students' election-related fears, or whether they could share information about students' academic progress with attorneys who requested it. Teachers were not sure if they could trust administrators and felt that administrators generally failed to train staff on this issue.

Like Gallo and Link (2016), we, too, found that teachers were largely "left to their own devices" (p. 189) with regards to working with undocumented students. As a result, they had to resort to agile advocacy in order to fulfill what they perceived as their roles in serving their students beyond providing instruction. They were agile in the sense that they occurred spontaneously in response to changing circumstances, such as the election of Donald Trump with his promises of stricter immigration enforcement. They were also agile in the sense that they were resourceful: teachers had no policy guidance and little support from leadership so they were left to improvise and take risks when they were uncertain about the permissibility of their actions. The teachers were unsure what particular actions violated district policy on political activities, leaving some to ignore the policy while others, like Nicole, withheld information they could have provided families out of a narrow interpretation of the policy. By contrast, other forms of advocacy teachers might engage in, such as pursuing better working conditions or stronger support for students in special education, typically have less ambiguous policy guidelines and intersections with confusing federal contexts such as immigration laws and proceedings. Immigration is also a politically polarizing issue, so advocacy in this area may 
involve greater risk than advocacy for other causes, depending on the political leanings of the community. It may further exacerbate the perception that teachers need to "go undercover" in order to serve their students and be cautious about whom they consult for advice. This reinforces the circle of silence and sustains the invisibility of undocumented students.

This study points to four needs for teachers: (a) more professional development on how to support and advocate for undocumented students and their families; (b) more opportunities for like-minded teachers to share resources and knowledge, lessen the sense of isolation in both their efforts and emotional labor, and build coalitions for advocacy; (c) district-level guidelines on how school personnel can protect these vulnerable students while following current policies and the law, and (d) explicit protections for teachers engaged in this work.

Ultimately, whole-school and whole-school-system climates of support are needed. Such structures would also help educators feel less alone and worried about whether they are “proselytizing," as Nicole called it, or otherwise violating rules. Many principals may, like these teachers, be unsure of what actions are permitted. In some cases, it may be that administrators avoid making schoolwide policies because their staff have strong and conflicting political views about immigration (Jefferies, 2014a). This is particularly problematic given widespread misconceptions among some school staff, such as the belief that undocumented students are not eligible for school and other services (Jefferies, 2014b).

Thus school systems need to ensure that all school personnel—including principals, front desk staff, bus drivers, school safety officers, and all others-know how they can support undocumented students, what to do in the case of ICE activity, and what resources they can direct families to (see also Jefferies, 2014a). Teacher education and education leadership programs can also do their part to ensure this information is as widely available as possible. 
Status consciousness in all of these domains would help minimize the "circle of silence" Jefferies (2014a) found among educators and its deleterious effects on guaranteeing inclusive and humanizing education for undocumented students. 


\section{References}

Braun, V., \& Clarke, V. (2012). Thematic analysis. In H. Cooper, P. M. Camic, D. L. Long, A. T. Panter, D. Rindskopf, \& K. J. Sher (Eds.), APA handbook of research methods in psychology, Vol. 2: Research designs: Quantitative, qualitative, neuropsychological, and biological (pp. 57-71). Washington, DC: American Psychological Association.

Castro-Salazar, R., \& Bagley, C. (2010). 'Ni de aquí ni from there'. Navigating between contexts: counter-narratives of undocumented Mexican students in the United States. Race Ethnicity and Education, 13(1), 23-40. doi:10.1080/13613320903549651

Cisneros, J., \& Lopez, A. (2016). DREAMzone: Educating counselors and human service professionals working with undocumented students. Journal for Social Action in Counseling \& Psychology, 8(2), 32-48.

Cohn, D., Passel, J. S., \& Gonzalez-Barrera, A. (2017, December 7). Rise in U.S. immigrants from El Salvador, Guatemala, and Honduras outpaces growth from elsewhere. Pew Research Center: Hispanic Trends. Retrieved from http://www.pewhispanic.org/2017/12/07/rise-in-u-s-immigrants-from-el-salvadorguatemala-and-honduras-outpaces-growth-from-elsewhere/

Dabach, D. B., Fones, A., Merchant, N. H., \& Adekile, A. (2018). Teachers navigating civic education when students are undocumented: Building case knowledge. Theory \& Research in Social Education, 46(3), 331-373. doi:10.1080/00933104.2017.1413470

Denver Public Schools. (2016, November 15). Immigration rights FAQ (Updated). Retrieved from https:/www.dpsk12.org/responding-to-immigration-concerns/

Flyvbjerg, B. (2001). Making social science matter, why social inquiry fails and how it might succeed again. Cambridge, UK: Cambridge University Press. 
Francis, W., Wachendorfer, A., \& Wilson, M. (2018). Migrant and asylum-seeking families: Analysis of federal government policies and procedures. Washington, DC: National Association of Social Workers. Retrieved from https://www.socialworkers.org/LinkClick.aspx?fileticket=nh8m0yWK1Zg\%3D\&portalid $=0$

Gallo, S., \& Link, H. (2016). Exploring the borderlands: Elementary school teachers' navigation of immigration practices in a new Latino diaspora community. Journal of Latinos and Education, 15(3), 180-196.

Gaytan, F. X., Carhill, A., \& Suarez-Orozco, C. (2007). Understanding and responding to the needs of newcomer immigrant youth and families. The Prevention Researcher, 14(4), 1014.

Gonzales, R. G. (2008). Left out but not shut down: Political activism and the undocumented student movement. Northwestern Journal of Law and Social Policy, 3, 219-239.

Gonzales, R. G., Heredia, L. L., \& Negrón-Gonzales, G. (2015). Untangling Plyler's legacy: Undocumented students, schools, and citizenship. Harvard Educational Review, 85(3), $318-341$.

Gonzales, R. G., Suárez-Orozco, C., \& Dedios-Sanguineti, M. C. (2013). No place to belong: Contextualizing concepts of mental health among undocumented immigrant youth in the United States. American Behavioral Scientist, 57(8), 1174-1199.

Jaramillo, A. (2006). La línea. New York, NY: Macmillan.

Jefferies, J. (2014a). Fear of deportation in high school: Implications for breaking the circle of silence surrounding migration status. Journal of Latinos and Education, 13(4), 278-295. 
Jefferies, J. (2014b). The production of "illegal" subjects in Massachusetts and high school enrollment for undocumented youth. Latino Studies, 12(1), 65-87.

Jefferies, J., \& Dabach, D. B. (2014). Breaking the silence: Facing undocumented issues in teacher practice. Association of Mexican American Educators Journal, 8(1), 83-93.

Landgrave, M., \& Nowrasteh, A. (2017, March 15). Criminal immigrants: Their numbers, demographics, and countries of origin. Immigration Research and Policy Brief No. 1. Washington, DC: Cato Institute. Retrieved from https://www.cato.org/publications/immigration-reform-bulletin/criminal-immigrantstheir-numbers-demographics-countries\#full

Lopez, J. K. (2010). Undocumented students and the policies of wasted potential. El Paso, TX: LFB Scholarly Publishing.

Mangual Figueroa, A. (2011). Citizenship and education in the homework completion routine. Anthropology \& Education Quarterly, 42(3), 263-280.

Mangual Figueroa, A. (2017). Speech or silence: Undocumented students' decisions to disclose or disguise their citizenship status in school. American Educational Research Journal, 54(3), 485-523. doi:10.3102/0002831217693937

Merriam, S. B. (1998). Qualitative research and case study applications in education. San Francisco, CA: Jossey-Bass Publishers.

Merriam, S. B., \& Tisdell, E. J. (2016). Qualitative research: A guide to design and implementation ( ${ }^{\text {th }}$ ed.). San Francisco, CA: Jossey-Bass.

Migration Policy Institute. (MPI; 2013, March). Major US immigration laws, 1790 - present. Migration Policy Institute. Retrieved from https://www.migrationpolicy.org/research/timeline-1790 
Migration Policy Institute. (MPI; 2014). Profile of the unauthorized populations: Virginia. Migration Policy Institute. Retrieved from https://www.migrationpolicy.org/data/unauthorized-immigrant-population/state/VA

Morton, J. (2011, October 24). Enforcement actions at or focused on sensitive locations. Policy number: 10029.2. Memorandum from the Director, U.S. Office of Immigration and Customs Enforcement.

National Academies of Sciences, Engineering, and Medicine. (NASEM; 2017). Promoting the educational success of children and youth learning English: Promising futures. Washington, DC: The National Academies Press. doi:10.17226/24677

National Conference of State Legislatures (2019, March 14). Undocumented student tuition: Overview. Retrieved from http://www.ncsl.org/research/education/undocumentedstudent-tuition-overview.aspx

Negrón-Gonzales, G. (2014). Undocumented, unafraid and unapologetic: Re-articulatory practices and migrant youth "illegality." Latino Studies, 12(2), 259-278.

Núñez, A., \& Holthaus, G. (2017). In-state tuition for undocumented students: A policy analysis. Journal of the Student Personnel Association at Indiana University, 47-63.

Parkhouse, H. (2017). Lessons on citizenship and democratic power literacy from undocumented youth. Critical Education, 8(5), 1-19. doi:10.14288/ce.v8i5.186125

Passel, J. S., \& Cohn, D. (2016, November 17). Children of unauthorized immigrants represent rising share of K-12 students. Pew Research Center. Retrieved from http://www.pewresearch.org/fact-tank/2016/11/17/children-of-unauthorized-immigrantsrepresent-rising-share-of-k-12-students/

Plyler v. Doe, 457 U.S. 202 (1982). 
Rong, X. L., Dávila, L. T., \& Hilburn, J. (2011). Working with immigrant children of "undocumented" and "mixed" families. In B. S. Fennimore \& A. L. Goodwin (Eds.), Promoting social justice for young children (pp. 93-109). New York, NY: Springer Publishers. doi:10.1007/978-94-007-0570-8_9

Staples, S. R. (2017, March 1). Guidance regarding school division responsibilities and actions under the law in reference to students and immigration. Superintendent's Memo \#059-17. Commonwealth of Virginia: Department of Education. Retrieved from http://www.doe.virginia.gov/administrators/superintendents_memos/2017/059-17.shtml

Suro, R., \& Singer, A. (2002). Latino growth in metropolitan America: Changing patterns, new locations. Brookings Institution, Center on Urban and Metropolitan Policy in collaboration with the Pew Hispanic Center.

U. S. Customs and Border Protection. (2019, March 5). CPB releases 2019 southwest border migration stats: Agency experiences record number of apprehensions/inadmissible family units. U.S. Customs and Border Protection. Retrieved from https://www.cbp.gov/newsroom/national-media-release/cbp-releases-fiscal-year-2019southwest-border-migration-stats

U. S. Department of Education. (USDOE; 2015, October 20). Resource guide: Supporting undocumented youth. U.S. Department of Education. Retrieved from https://www2.ed.gov/about/overview/focus/supporting-undocumented-youth.pdf

Wasser, J. D., \& Bresler, L. (1996). Working in the interpretive zone: Conceptualizing collaboration in qualitative research teams. Educational Researcher, 25(5), 5-15. 
Table 1. Participant demographics

\begin{tabular}{|c|c|c|c|c|}
\hline $\begin{array}{l}\text { Pseudo- } \\
\text { nym }\end{array}$ & Gender & Job title/position & $\begin{array}{l}\text { Years in } \\
\text { K-12 } \\
\text { schools }\end{array}$ & $\begin{array}{l}\text { Race/ } \\
\text { ethnicity }\end{array}$ \\
\hline Anna & $\mathrm{F}$ & High school ESOL ${ }^{\text {a }}$ teacher & 2.5 & White \\
\hline Brin & $\mathrm{F}$ & Middle school ESOL teacher & 10 & White \\
\hline Caroline & $\mathrm{F}$ & Spanish teacher grades 6-8 & 2 & Hispanic \\
\hline Catherine & $\mathrm{F}$ & Elementary school ESOL teacher & 20 & White \\
\hline Deborah & $\mathrm{F}$ & $\begin{array}{l}\text { Elementary school special education } \\
\text { teacher }\end{array}$ & 27 & White \\
\hline Donna & $\mathrm{F}$ & Elementary ESOL teacher & 20 & White \\
\hline Evan & $\mathrm{M}$ & High school ESOL teacher & 2 & White \\
\hline Jacob & M & Middle school ESOL teacher & 1 & White \\
\hline Kelly & $\mathrm{F}$ & High school ESOL teacher & 4 & White \\
\hline Leah & $\mathrm{F}$ & $\begin{array}{l}\text { High school ESOL instructional } \\
\text { assistant }\end{array}$ & 10 & Black \\
\hline Maria & $\mathrm{F}$ & Elementary school ESOL teacher & 12 & $\begin{array}{l}\text { Black/ } \\
\text { Hispanic }\end{array}$ \\
\hline Molly & $\mathrm{F}$ & Middle school ESOL & $25+$ & White \\
\hline Nicole & $\mathrm{F}$ & High school ESOL teacher & 1.5 & White \\
\hline Olivia & $\mathrm{F}$ & Elementary school ESOL teacher & 18 & White \\
\hline Prudence & $\mathrm{F}$ & Elementary school ESOL teacher & $\begin{array}{l}9 \text { as a sub/ } \\
3 \text { full-time }\end{array}$ & Hispanic \\
\hline Rachel & $\mathrm{F}$ & High school ESOL teacher & 11 & White \\
\hline Stacy & $\mathrm{F}$ & Middle school ESOL teacher & 15 & White \\
\hline Victoria & $\mathrm{F}$ & High school ESOL teacher & 8 & White \\
\hline
\end{tabular}

Source: All information reported in table was self-identified by participants through an openended demographic questionnaire.

${ }^{\mathrm{a}} \mathrm{ESOL}=$ English to Speakers of Other Languages. 